\title{
STRUCTURAL DRIFT: REFLECTIONS ON SCIENCE INNOVATION POLICY IN POLAND
}

\begin{abstract}
The subject of this article is an analysis of Polish scientific and innovation policy. The author made forecasts about the development of policy in the context of the reform implemented in Act 2.0. An attempt was made to formulate a forecast about the impact of the policy on the level of innovation in Poland. The author was critical of the changes implemented under the so-called Gowin reform and points to potential threats related to, among others, the hierarchization of Polish universities and maintaining the so-called Matthew effect: strengthening strong academic centers and weakening the inferior ones. The complexity of the issue of innovativeness and the limited influence of R\&D expenditures on the level of innovativeness of a given country was pointed out. The author also referred to the Wissema's concept of the third generation university, which critically assesses changes in higher education, especially according to the idea of new public management, including university parameterization based on the points awarded for indexed journals.
\end{abstract}

Keywords: innovations, innovation policy, science innovation policy, academic entrepreneurship.

\section{INTRODUCTION}

The subject of the article is the prognoses of the development of Polish science innovation policy. The Lisbon Strategy (European Council, 2000) assumed radical economic transformation of the EU, which was expected to defeat the USA and Japan in the innovation competition. Thus, the EU policy focused on the creation of national innovation systems, which were to institutionally enforce the collaboration between the private sector and the research and development (hereinafter R\&D) sector through various institutions controlled and coordinated by the state. Consequently, the concept of innovation reinforced the economic and commercial aspects in science policy and was put in the centre of it (Pelkonen, 2008). According to Gibbons, it was the last stage in the evolution of the scientific policy of the post-war period from the phase of policy for science, through science in the policy arena, to the period of technological innovations policy (Gibbons et. al., 1994).

The national innovation system in Poland is classified as the model in transition and the innovations have mainly the imitation character (Bukowski \& Śniegocki, 2011). There are some institutions in the innovation system, such as clusters or science and technology parks,

\footnotetext{
1 Agnieszka Karpińska, DSc, PhD, Associate Professor, Institute of Sociology, University of Bialystok, ul. Plac NZS 1, 15-420 Białystok; e-mail: agnieszka.karpinska@uwb.edu.pl. ORCID: 0000-0002-9316-8413.
} 
but their innovative activity involves mainly imitation and is incommensurate with the organizational and administrative base (Kwieciński, 2018). Therefore, the Polish system of innovation is considered to be in statu nascendi: although individual institutions are functioning, stable relationships have yet developed between its components (Bukowski \& Śniegocki, 2011). It is worth mentioning that the Polish innovation system is mostly based on public institutions, which have been (and will be for the next few years) financed with EU resources. Innovation activity displayed by the private sector is negligible and mostly takes place in Polish branches of foreign companies. Universities do not conduct substantial innovation activity, either. In the regions of Poland with a low level of industrialization, faint (and often the only) innovation activity is generated in state institutions, whose functioning is not verified by market effectiveness. Obviously, there are places where innovation activity is dynamically developing, but these are scarce cases that only occur in huge agglomerations. Thus, the Polish system of innovation is characterized by the low efficiency of imitation innovation policy, excessive institutionalization of the Polish national system incommensurate with its R\&D resources, low profitability (Poland has one of the lowest efficiency ratio in the $\mathrm{EU}$ ) and excessive financial dependence on EU funds (Gasz, 2015). In this context, the question of the future of innovation leads to rather pessimistic forecasts. The presented discussion on forecasts concerning the development of science innovation policy in Poland is based on publications, analyses and reports on innovation as well as critical analysis of literature of the field.

\section{SCIENCE INNOVATION POLICY}

Forecasts concerning the development of Polish innovation policy refer to the growing role of the sector of science in innovation processes. It is the result of many factors, i.a., the problem of brain drain pointed out in benchmarking analyses (Klimczuk-Kochańska, Proniewski, Popławski, Niedźwiecki, Perło, Skibicka, Juchnicka, Nikitorowicz, 2012) or the increasingly popular idea of learning regions (Gasz, 2015). The experience of collaboration between scientific institutions and the world of business to date clearly shows that the role of academia in generating innovation activity is overestimated. Generally, most Polish universities are not innovative, and the private sector is not interested in cooperating with universities functioning completely out of the market reality. Although 30 years have passed since the system transition, the value of scientific exploration, i.e., the pursuit of the truth, has not been properly acknowledged since the post-war period, either in science policy or in the real activity of universities. Commercialization of universities may be possible, but definitely not in the present phase of development of Polish science. Before universities in post-communist countries adapt to the market reality (if they do so at all), they need to work out stable conditions for R\&D activity. From the beginning of the system transition, change has been the most distinctive feature of Polish science. The state of reform, referred to in source literature as constant reinstitutionalization (Sadowski, 2014), is going to continue in the nearest future. The $2.0 \mathrm{Law}$, implemented by the Ministry of Science and Higher Education in October 2019, introduces many solutions typical of the new public management policy, connected i.a., with the evaluation of institutions and academics' research work in accordance with standardized rules (Dz.U. 2018, item 1668). M. Kwiek, one of the co-authors of the new law, considers international comparative data to be the starting point for creating science policy. 
$\mathrm{We}$ - as the system, particular institutions and their agendas as well as individual researchers located in various parts of the system - are becoming almost transparent for the world, and if particular elements are not visible in the global perspective, it means our situation is even worse. It is because the age of visibility (and measurability) has come for all the most important dimensions of university (Kwiek, 2018).

Therefore, the Constitution for Science stresses the need for scientists to publish in journals present in international bases such as Scopus or the Web of Science, which help researchers from all over the world access that content. In the evaluation process, such publications receive more points. In the evaluation following the new rules, universities will mostly be assessed using the criterion of indexed scientific production. In accordance with the strategic choice made in the law, the level of an institution is determined by its scientific accomplishments, not the degrees of staff members.

One of the most important changes, whose consequences may not yet be understood by everyone, is recognizing the significance of publications and research grants (ultimately affecting the income and scientific production structures and their temporal changes) instead of the number of new professors and habilitations (Kwiek, 2018.).

In the context of structural changes, the reform introduced by minster Gowin corresponds to the idea of learning regions and introduces solutions mobilizing scientific institutions to establish broader cooperation with the environment. The Law provides i.a., for the possibility to create federations. The federation will be entitled to joint evaluation in a specific field, carry out scientific activity, educate doctoral students, grant scientific degrees and commercialize the effects of scientific activity. The solution with crucial importance for the future of the Polish science, and indirectly, for their research and innovation potential, is the introduction of so-called 'flagship universities' (although this term is not explicitly mentioned in the Law). The best academic centers will be able to fight for extra financial resources as part of the cyclical program Inicjatywa doskonatości uczelnia badawcza [Excellence Initiative - Research University]. The best ten universities can obtain at least $10 \%$ extra resources granted as part of the subsidy for 6 years. The other institutions which meet the contest requirements may obtain extra $2 \%$. Obviously, it is only possible for a university to receive category A or A+ if its employees have a high rate of indexed scientific publications and apply for scientific grants. Thus, the Excellence Initiative program strengthens alternative paths of obtaining resources for research, and as a result, it supports vertical diversification of Polish academic institutions.

Resources for research produce more research, which means that grants are necessary for new publications and research projects in most disciplines, but to obtain grants (from the National Science Centre or the European Research Council), you need to have the best publications. Thus, it is a vicious circle: without best publications there are no new grants for research, so there is no new research, and so there are no new publications or citations. For institutions, this is one way to collapse (Kwiek, 2018). 
The money will go to the small group of the few best universities in Poland, especially the University of Warsaw and the Jagiellonian University. The contest allocation of grants from the National Science Centre will result in more good (highly indexed) publications. In institutions that receive financing, the pool of indexed publications is systematically growing, allowing to apply for further resources from the Excellence Initiative program. This results in the process of accumulation of prestige, and hence, of resources. The Matthew effect - strengthening the strong and weakening the weak - is more powerful in such institutions than in others, which do not use context financing or use it to a little extent. It is hard to forecast to what extent the proposals will affect the innovation activity of higher schools, especially that the new law does not introduce any revolutionary changes in cooperation with business. Many changes have already been introduced, first by means of the Small Innovation Law (Dz.U. 2016, item 1933), and then, another Innovation Law (Dz.U. 2018, item 1668). The proper regulations concerning technology transfer are an imitation of the current regulation. The division into indirect and direct commercialization is still in place. Further, the Constitution for Science takes over the previous model of procedure of so-called "enfranchisement of researchers", i.e., their obtaining the right to the results of R\&D works. The present principles of distribution of profits from commercialization between the researcher and the university will not change. Asked whether university faculties will focus on commercial parts of their disciplines only, H. Izdebski responds:

This trend is becoming the mainstream in Poland, while in other countries, it is beginning to recede. The task of the university is to educate good professionals, not to assume their role and compete with them. And the concept of entrepreneurial university, which was not created in Poland, does involve such dangers. (...) Yes, I know the spirit of this reform is to combine basic research, applied R\&D works into one technological series. But it's impossible to do. Einstein was not an implementation researcher. What is more, for some time, his theories were regarded as a fad, which may be interesting but will definitely not be useful. Would he fit the entrepreneurial university? (Izdebski, 2018b).

We might ask instead whether in the reality of Polish academia there is a chance for the development of entrepreneurial attitudes, which can ultimately stimulate innovation. Analyzing the assumptions of the reform introduced with the $2.0 \mathrm{Law}$, one may have the impression that in some academic centres the chance definitely exists. The leading Polish universities, which will make the core of flagship research centers in the nearest future, will become the main center of research with a high index of scientific production. Universities will become commercial, but only as regards market mechanisms of applying for grants. Innovation policy based on the assumption that research is the main source of innovation irrespective of the amount of financial expenditure will never be effective. The phenomenon of innovation is something in between production and marketing. New solutions may result from R\&D work, but it does not have to be so. Innovative things are mostly those that sell, regardless of the cognitive value of the new product or service. Hence, the political discourse legitimizes some myths concerning innovation, constructing the rhetoric contrary to the scientific discourse. Therefore, it must be emphasized here: from the perspective of scientific discourse on innovation, postulates assuming a direct influence of R\&D expenses 
on the level of innovation deserve criticism. Although this assumption is often repeated in EU strategies and present in scientific literature, it is actually a hypothesis, proved false in empirical research. "Actually, there is no clear correlation between the level of research expenditure and the level of innovation" (Jaruzelski, Dehoff, Bordia, 2005). Unfortunately, the political vision is being implemented by the Ministry of Science and Higher Education, which is well evidenced in the following quotation from the recitals of the Constitution for Science: "Uuniversities and other research institutions carry out the mission of special importance for the state and the nation: they contribute considerably to the innovativeness of economy, to cultural development, and to shaping the moral standards present in the public life" (Dz.U. 2018, item 1668).

The belief in the key role of universities in the innovativeness of the economy shows the misunderstanding of the idea of innovation and the lack of scientific knowledge in this regard. The experience of western countries clearly shows that the stress on the commercialization of research does not guarantee the expected financial profit and only leads to the marginalization of basic research and reduced quality of didactic work (Izdebski, 2018a). But in the context of innovation, the main question is different: will the predicted, almost certain, development of the best Polish science centers - measured with indexed scientific production and active research work - generate the expected (and symbolically present even now in the Recitals of the Constitution for Science) increase in innovation activity? What about the institutions that do not meet the threshold of Excellence Initiative? And what about those that do not even obtain the Regional Initiative title? What effect will the strengthening of the vertical structure of Polish research centers have for regions' innovativeness if we take into consideration the Matthew effect? Will the best universities be the most innovative? The experience of western countries shows it is fitting to be skeptical about such straightforward theses. The title Excellence Initiative will not have a direct positive impact on the innovation potential. Universities may carry out impressive research activity, which I consider to be their main mission in the context of the discussed reforms, but it does not mean at all that they will be more innovative than other institutions. I would rather see some influence on innovative attitudes in the indirect result of investment in human capital, which the 2.0 Law forces the authorities to do. The Constitution for Science undermines the current assumption that recruitment policy and promotion policy do not really matter for the university profile. In the situation of closely binding financial mechanisms with the measurable, prestigious scientific production, the key to the research character of selected institutions will only be talented staff: productive, engaged in research, and having the potential for obtaining additional, external financing of research (Kwiek, 2018). Supposedly, employees matching this profile will display some innovation activity, provided that in the reality of standardized scientific production, innovation will be profitable for academics. Thus, universities will compete with each other, and the effect of this competition is easy to predict and already forecast in source literature: the process of stratification will deepen. And innovation? Despite pompous and inaccurate declarations included in the Recitals, innovation in Poland usually occurs in places where decision-makers do not really expect it. 


\section{THE $4^{\mathrm{TH}}$ GENERATION POLICY. THE $3^{\mathrm{RD}}$ GENERATION UNIVERSITY}

One of the strongest trends forecast with reference to the development of Polish universities is the direction of deepening stratification. The 2.0 Law enhances the processes of hierarchization by introducing solutions resulting in the Matthew effect: stronger institutions will strengthen, and the weak ones will weaken. The pillar of research is to be research activity resulting in scientific production in journals with a high impact factor. The introduced changes result from the imperative of visibility of Polish science centers, connected with the growing importance of standardized, international comparative data. The introduction of technocratic principles of evaluation of universities and individual work of researchers may have positive effects concerning the level of their scientific activity. Probably, there will be some strategies aimed at evading regulations and attempting to maintain the status quo, but it seems that the mechanism of strictly binding the financing of an institution with its parametric assessment will discourage others from making such attempts. From the perspective of development of the research potential of the Polish academia, we may pin our hope in Gowin's reform. However, the Constitution for Science does not introduce the needed and expected solutions concerning the innovativeness of Polish universities. In the political discourse, the statement of the lack of significant influence of R\&D activity on innovation activity, often repeated by the author, is ignored at best. And yet, the dynamic development of research on innovation and experience of developed countries, which have been introducing various scenarios of development for many years, shows that the key for stimulating innovative activity is not R\&D activity but entrepreneurial attitudes of academics, students and owners of private companies. Innovation is commercialization. A crazy inventor with a number of patents to his credit is not an innovator. An innovator is first of all a practitioner who knows how to sell their idea. "An idea in itself is nearly worthless. It only assumes some worth in the phase of development and marketing" (Wissema, 2005). That's all. As shown by research carried out by the European Innovation Scoreboard, even a high number of patents registered in a country does not correlate with high innovation activity. Innovation is most closely related to marketing, and less to technology. The sector of social innovation, currently growing in importance, is mostly based on institutional, ecological, cultural and behavioural innovations. New forms of innovation also lead to changes in global innovation policy, which is referred to as the $4^{\text {th }}$ generation policy, stressing the interdisciplinary character and context of usability of social innovation. The reorientation of international strategy causes changes in the discourse of science policy, in which the idea of modern entrepreneurial university, called the $3^{\text {rd }}$ generation university, is used more and more extensively. This concept was presented by J. G. Wissema, who refers to the new mission of universities, that is, educating and supporting entrepreneurs which try to introduce to the market some technological concepts, ideas or technologies (Wissema, 2005). Generally, the $3^{\text {rd }}$ generation university conducts research activity, and hence, it employs entrepreneurial academics and educates future entrepreneurs. The idea of entrepreneurship constitutes the scientific and didactic activity of university. Thus, the author demystifies innovation as a gift of outstanding individuals and focuses on the ability to commercialize the invention: "An idea, even a good one, has no worth. An invention may have some worth. But innovation may be worth a fortune", he argues (Wissema, 2005). Wissema's assumptions concerning didactics are based on the belief that entrepreneurship is an attitude that can be taught and acquired as part of university education. 
Yes, entrepreneurs are dreamers with passion, who pursue their dreams. If it is the matter of passion, entrepreneurs do not need any special gene of success. Anyone who is ambitious, wants to learn and is persistent can become an entrepreneur. It's not magic. You can learn anything as long as you want to, he concludes (Wissema, 2005).

The model of the $3^{\text {rd }}$ generation university is based on so-called seven-pointed star and includes, among others, the following elements: commercialisation of know-how, ambition to become an international centre of technology transfer, introduction of research evaluation based on direct control with the system of appeals (expert evaluation), independence from the state authorities as there is no direct financing of the university from the budget, replacement of faculties with specialised thematic entities of an entrepreneurial nature, replacing faculties with specialist, entrepreneurial subject teams having their own management and establishing their own networks of cooperation, English as the basic language of communication (Wissema, 2005).

It is hard not to comment on the revolutionary character of the changes proposed by Wissema. In the context of discussion about the Polish science policy, the model of $3^{\text {rd }}$ generation university is undoubtedly very futuristic, and perhaps even fantastic. It is worth pointing out, however, that it mostly resulted from the criticism of some assumptions currently promoted by Gowin's reform. Wissema harshly criticizes the idea of so-called scientific production, on which he comments:

Finally, research itself has become an object of bureaucracy. Administrators boasted about an increase in research productivity (again, a term taken from commercial organizations), and the measure of that "productivity" was the number of publications and citations. The system was very beneficial for research that repeated earlier theses. Independent and innovative thinking was the casualty of such an attitude, and mediocrity has become the standard (Wissema, 2005).

Sadly, universities still measure the results of research with the number of scientific publications: Not only publications are counted. It also refers to the number of citations, which is determined with complex indices, where different scientific journals are classified with regard to the count of citations and the positions of particular researchers are expressed in the form of a weighted average of citations of their works. It is a typical way of thinking from the industrial period, which cannot be used in the information age. It stimulates the formation of pseudo science (Wissema, 2005). In the context of the discussion on the role of Polish universities in the development of innovation activity, it is also worth pointing out the importance of universities in developing entrepreneurial attitudes of academics and students. In Poland this issue is marginal and is mostly studied in relation with EU programs promoting and financing this issue. Scientific and political reflection oriented at the development of innovation through stimulating entrepreneurial attitudes is actually absent. Thus, the prognosis is that in the nearest future the direction of development of potential of Polish universities will not contribute to an increase in innovative attitudes, even if it will result in observable (or rather visible) growth in scientific production. 


\section{CONCLUSIONS}

The linear model of forcing innovation through science (the supply model) dominates in Poland, while in the EU it has already become obsolete and been replaced by the model of innovation "dragged" by the market (the demand model). The forecasts concerning the development of innovation and science policy suggest that in the nearest future, this trend will change considerably. The concept of regional innovation systems, based on the idea of learning regions, overestimates the importance of investment in R\&D potential as a motor of innovation.

Apart from many economic factors whose dynamics is hard to predict, the reorientation of Polish innovation policy should avoid reproducing ineffective assumptions of EU strategies. One of the most serious mistakes, often pointed out in source literature, is treating research as a source of innovation (Ciborowski, 2014). "Actually, there is no clear correlation between the level of research expenditure and the level of innovation (Jaruzelski, Dehoff, Bordia, 2005). Another trap may be the overestimation of the factor of knowledge in creating market processes, and innovation is definitely one of them. This erroneous thinking has also been present for many years in European- and national-level innovation strategies. Although the concept of regional systems changes the perspective of thinking about innovation from the national to the local level, the mechanisms of distribution of financial resources are still the same. Evidently, the main target is the level of R\&D expenditure. It is worth pointing out that as a result of such a policy, the European market is becoming less flexible and new, innovative enterprises are not established. The market is still dominated by big corporations, which use the support of innovation policy to become monopolistic and make a trustified economic structure. As argued by Ciborowski, this will result in higher expenses for R\&D but will not increase innovation (Ciborowski, 2014). L. Zienkowski expresses a similar opinion, concluding the reflections on the impact of knowledge capital on economic growth as follows:

Assuming as the starting point the realistic view of the situation - relatively low R\&D expenditure, especially in the sector of enterprises, the insufficient number of highly qualified research workers and engineers, relatively low level of education capital (formal knowledge) and low level of literacy (actual knowledge, not the formal education level) - substantial growth of R\&D expenditure in Poland is unlikely to have far-reaching effects, even if such growth was possible (Zienkowski, 2008).

While the EU innovation policy can be called an instrument which "does not guarantee effectiveness and may even do harm to entrepreneurial processes" (Ciborowski, 2014) the idea of smart development of regions involves a danger that the knowledge on regional determinants will neither do harm nor help innovation. For many years, the national and regional innovation policies have had their strategy based on a wrong assumption, i.e., considering R\&D expenditure as a source of innovation, and consequently, evaluating innovation using the criterion of technological activity, excluding social and economic activity (Ciborowski, 2014).

The most effective method of influencing innovative entrepreneurship is the possibility to use properly the resources and market opportunities available for entrepreneurs, and the 
stakeholders of the regional innovation system cannot do much about it. However, it is the institutions responsible for regional policy that can shape the quality of human capital - the factor of special importance in peripheral countries and regions.

The problems of peripheral countries are aggravated by privileges for foreign capital regarding access to knowledge, but also the immaturity or incompetence of political elites, as well as their low sensitivity to social problems. Wise authorities learn not to renounce the most valuable resources, that is, human resources (Popławski, Popławski, 2016).

Thus, in the context of discussion on the future of innovation in Poland, investment in human resources should be treated as the priority. Innovativeness is always hard to learn, because it is a characteristic of few, and the massive outflow of entrepreneurial individuals from imitation countries is not only becoming a social fact but also considerably worsens economic losses and prevents the country from overcoming backwardness or so-called middle income trap, which is evidenced i.a., by the weakening pension system, brain drain, and exogenous growth (Popławski, Popławski, 2016). Unfortunately, science policy is going to deepen the hierarchy of Polish universities, only few of which have a chance to become flagship centers with a stable, systematic source of financing. The perpetuum mobile of development of Polish academia is to be the high rate of scientific production, whose influence on the innovativeness of Polish economy is lower than assumed by the authors of the law. The trend of imitating foreign solutions rooted in the idea of new public management is consolidating in Polish innovation policy. However, this process occurs later than in the model countries, which results in copying solutions whose effectiveness proved to be lower than initially assumed. Polish innovation policy repeats the mistakes of developed countries such as overestimating the impact of R\&D activity and standardized scientific production on innovation activity. Unfortunately, concentration on the macrostructural model of national innovation system drawing on the experiences of EU countries has led to the marginalization of importance of human capital in the development of innovation. An individual with their intellectual and entrepreneurial potential is not the addressee of systemic innovation policy or science policy. Both strategies are under a great influence of industrial rhetoric, promoting measurable and visible indices of human activity. But innovativeness, as a feature of few individuals, mostly requires investment in human capital. One could ask a provocative question whether innovation can be a change predicted by the authors of the policy in advance (Ciborowski, 2014). Probably not. Decision-makers have limited influence on the dynamics of global economic processes shaping the market of innovation, although they have a greater impact on shaping the economic development of regions. And yet, it is more and more often argued in source literature that innovation is a very complex and dynamic phenomenon, and its occurrence is practically unpredictable (Miettinen, 2002). With the development of international comparative research on innovation, the list of determinants of innovation is becoming shorter and shorter (Godin, 2002; Jasiński, 2013). Researchers have undermined i.a., the thesis of the key impact of R\&D activity (Zienkowski, 2008). More and more studies point to the lower than expected impact of infrastructure of national innovation systems (Nazarko, 2013; Niosi, 2002; OkońHorodyńska, 2012; Popławski, Popławski, 2016). Research results and the increasing 
knowledge on the study of innovation support the thesis of the crucial importance of human capital in creating innovation (Mytelka, Smith, 2002). The essence of innovation policy should be the shaping of modern mechanisms of development of human capital, especially as regards entrepreneurship. And yet, in Poland the importance of education in the development of innovation is marginalized. Innovation policy focused on the idea of learning regions introduces significant changes in this respect. However, the thesis of the priority importance of cooperation between institutions of the academia, business and local government a priori assumes a sufficient level of human capital of particular stakeholders. Still, research results clearly show that the high enrollment ratio of the Polish society does not correlate with other elements of human capital, e.g., with the level of entrepreneurial attitudes of individuals, particularly academics and students (Kleiber; Kleer, Wierzbicki, Galwas, Kuźnicki, Sadowski, Strzelecki, 2011). "You need to learn how to walk before you learn how to run", we could metaphorically sum up the relations between regional innovation systems and the level of human capital. It is only a higher level of education of the society and the intellectual elites developed within it, supported with socio-economic policy and a change in mentality of the society towards innovation, that may accomplish the situation in which the internal scientific and technological thought will be the basic factor of development (Zienkowski 2008).

Unfortunately, the science policy represented in the 2.0 Law also clearly depreciates didactic scientific activity, which is not subject to international standardization or comparisons, and thus, does not play a significant role in the parametric assessment of universities. The few factors on which the state policy may have a real impact are marginalized in Poland, and the presented changes are going to reinforce this trend in the foreseeable future.

\section{REFERENCES}

Bukowski, M., Śniegocki, A. (2011). Globalizacja w wymiarze lokalnym [w:] Bukowski, M. red., Zatrudnienie w Polsce 2010 - integracja i globalizacji. Warszawa: Instytut Badań Strukturalnych.

Ciborowski, R. (2014), Instrumenty polityki innowacyjnej Unii Europejskiej i ich wplyw na działalność proinnowacyjna przedsiębiorstw [EU Innovation Policy Instruments and Their Impact on the Pro-Innovation Activity of Enterprises]. "Optimum. Studia Ekonomiczne" nr 6(72).

European Council. (2000). Presidency Conclusions. Lisbon European Council 23 and 24 March 2000.

Gasz, M. (2015). Kierunki zmian $w$ polityce innowacji $w$ Polsce $i w$ Unii Europejskiej [Directions of Changes in Innovation Policy in Poland and in the European Union]. "Studia Ekonomiczne. Zeszyty Naukowe" nr 214.

Gibbons, M., Limoges, C., Nowotny, H., Schwartzman, S., Scott, P., Trow, M. (1994). The New Production of Knowledge. The Dynamics of Science and Research in Contemporary Societies. London: SAGE.

Izdebski H. (2018a). Ile jest nauki w nauce? [How Much Science Is There in Science?]. Warszawa: Wolters Kluwers. 
- (2018b). Interview conducted on 24 September 2018 by K. Sobczak for Prawo.pl. 2018b [access: 25.09 .2018 ]. Access on the internet: https://www.prawo.pl/student/wplyw-ustawy20-na-badania-podstawowe-opinia-prof-izdebskiego,301182.html.

Jasiński, A. H. (2006). Innowacje i transfer techniki w procesie transformacji [Innovations and Technology Transfer in the Process of Transition]. Warszawa: Difin.

Jaruzelski B., Dehoff K., Bordia R. (2005). Money isn't everything: the Booz Allen Hamilton Global Innovation 1000. Booz Allen Hamilton, McLean.

Kleiber, M., Kleer, J., Wierzbicki, A., Galwas, B., Kuźnicki, L., Sadowski, Z., Strzelecki, Z. (2011). Raport Polska 2050. Warszawa: Wydawnictwo Komitetu Prognoz 'Polska 2000 Plus', Polska Akademia Nauk.

Klimczuk-Kochańska, M., Proniewski, M., Popławski, T., Niedźwiecki, A., Perło, D., Skibicka, E., Juchnicka, M., Nikitorowicz, A. (2012). Benchmarking regionalny czynników innowacyjności województwa podlaskiego w kontekście RSI. Synteza raportu [Regional Benchmarking of Innovation Factors of Podlaskie Voivodeship in the Context of RSI. Report Synthesis]. Białystok: Wydawnictwo Uniwersytetu w Białymstoku.

Kwiek, M. (2018). Ustawa 2.0 a mierzalność i porównywalność osiagnięć naukowych [The 2.0 Law and the Measurability and Comparability of Scientific Accomplishments]. "Nauka" nr 1 .

Nazarko, J. (2013). Regionalny foresight gospodarczy. Scenariusze rozwoju innowacyjności mazowieckich przedsiębiorstw, [Regional Economic Foresight. Scenarios of Innovation Development of Enterprises from the Mazowsze Region]. Warszawa: Związek Pracodawców Warszawy i Mazowsza.

Niosi, J. (2002). National Systems of Innovation are 'x-efficient' (and x-effective). Why Some are so Slow Learners?. "Research Policy" nr 31.

Okoń-Horodyńska, E. (2012). Małopolska Regionalna Strategia Innowacji: kolejne wyciskanie 'brukselki' czy szansa na ambitna polityke rozwoju? [Małopolskie Regional Innovation Strategy: Another Attempt to Make Use of Brussels' Money or an Opportunity of an Ambitious Development Policy?]. "Małopolska Strategia Rozwoju” nr 1-2.

Pelkonen, A. (2008). The Finnish Competition State and Entrepreneurial Policies in the Helsinki Region. Helsinki: Helsinki University Press.

Popławski, T., Popławski, K. (2016). Szanse i pułapki postforrdyzmu w fazie lean management dla rozwoju państw peryferyjnych [Opportunities and Traps of Post-Fordism in the Phase of Lean Management for the Development of Peripheral States] [w:] Popławski, W. T., Kaczorowska-Spychalska, D., red., "Przedsiębiorczość i zarządzanie. Nowe trendy w zarzadzaniu - wybrane uwarunkowania innowacyjności i konkurencyjności” $\mathrm{nr} 17, \mathrm{z} .7, \mathrm{cz} .3$.

Sadowski, I. (2014). Współczesne spojrzenie na instytucje: ewolucja pojęć, problem modelu aktora i poziomy analizy instytucjonalnej. „Przeglad Socjologiczny” nr LXIII/3.

Ustawa z dnia 4.11.2016 r. o zmianie niektórych ustaw określających warunki prowadzenia działalności innowacyjnej [Act of 4 November 2016 Amending Certain Acts Defining the Conditions of Conducting Innovative Activity] (Dz.U. 2016, item 1933).

Ustawa z dnia 9.11. 2017 r. o zmianie niektórych ustaw w celu poprawy otoczenia prawnego działalności innowacyjnej [Act of 9 November 2017 on Amending Certain Acts to Improve the Legal Environment of Innovative Activities] (Dz.U. 2017, item 2201).

Ustawa z dnia 20.07.2018 r. o szkolnictwie wyższym i nauce [Act of 20 July 2018 - Law on Higher Education and Science] (Dz.U. 2018, item 1668). 
Wissema, J. G. (2005). Technostarterzy. Dlaczego i jak [Technostarters, Why and How?]. Warszawa: Polska Agencja Rozwoju Przedsiębiorczości.

Zienkowski, L. (2008). Czy kapitat wiedzy oddziałuje na wzrost gospodarczy - spojrzenie ekonomisty [Does Knowledge Capital Have an Influence on Economic Growth: an Economist's Perspective]. "Przeglad Socjologiczny" nr 57(3).

DOI: $10.7862 /$ rz.2021.hss.29

The text was submitted to the editorial office: October 2020.

The text was accepted for publication: December 2021. 